\title{
English Word-Formation Types in Croatian: The Case of Morphological Adaptation of Noun Phrases in Economic Terminology
}

\begin{abstract}
The influx of Anglicisms is no longer limited to simple and open-class words in a lexicon, but it is also open to complex words and multiword expressions (e.g., phraseological units and simple sentences). Complex words are not only borrowed with their original English affixes (prefixes), but can also be formed with the addition of bound morphemes from the recipient language. This paper aims to shed more light on current Anglicisms in terms of noun phrase formation and adaptation from economic terminology into the Croatian language. It presents the results of transmorphemisation within a three-degree adaptational framework: zero, partial/compromise and complete transmorphemisation. Each adaptational degree is exemplified by English models and Croatian replicas, all described and explained in these terms. For the sake of comparison, illustration and the applicability of the model, some examples of noun phrases found in Russian, Slovene and Serbian are also provided.
\end{abstract}

Keywords: English; Croatian; Anglicisms; noun phrases; adaptation; zero; compromise and complete transmorphemisation

\section{Angleške besedotvorne vrste $\mathbf{v}$ hrvaščini: primer morfološke adaptacije samostalniških zvez v ekonomski terminologiji}

\section{POVZETEK}

Dotok anglicizmov v jezik ni več omejen zgolj na enostavne polnopomenske besede, ampak zajema tudi sestavljene besede in večbesedne izraze (npr. frazeološke enote in enostavčne povedi). Sestavljene besede se prevzemajo skupaj z angleškimi ponami (predponami), hkrati pa se lahko tvorijo tudi z dodajanjem morfemov jezika prejemnika. Članek obravnava tvorjenje samostalniških anglicizmov ter njihovo adaptacijo v hrvaški jezik na področju ekonomske terminologije. Predstavljeni so rezultati transmorfemizacije v okviru tri-stopenjskega procesa adaptacije: ničta, delna/kompromisna in popolna transmorfemizacija. Vsaka stopnja adaptacije je podprta in razložena $\mathrm{z}$ angleškimi zgledi in hrvaškimi replikami. Za potrebe primerjave, predstavitve in uporabnosti modela so za nekatere samostalniške besedne zveze navedeni primeri iz ruskega, slovenskega in srbskega jezika.

Ključne besede: angleščina; hrvaščina; anglicizmi; samostalniške besedne zveze; adaptacija; ničta; kompromisna in popolna transmorfemizacija 


\section{English Word-Formation Types in Croatian: The Case of Morphological Adaptation of Noun Phrases in Economic Terminology}

\section{Introduction}

So far, a lot has been said about the adaptation of Anglicisms or other -isms (e.g., Russianisms, Italianisms, Gallicisms, etc.) in various European languages at different linguistic levels (phonological, morphological and lexico-semantic). ${ }^{1}$ Globalisation and its implications for wor(l)d transformations are huge. The English language has at least a two-fold function in this process: direct or incidental function as a medium of communication, and indirect or coincidental function as a medium of transformations within the linguistic structures of receiving languages. The influx of English lexemes is becoming more evident in both formal and informal contexts (i.e., replicas become more susceptible to models). ${ }^{2}$ In this research we present the widening of morphological analysis on noun phrases that are Anglicisms, as a result of which a revised methodology of their three-degree morphological adaptation and classification is both devised and applied (zero, partial/compromise, and complete transmorphemisation). Our aim is to present and test the applicability of the proposed transmorphemisational approach on a number of Anglicisms in Croatian economic terminology, and to examine their formational possibilities when compared with the analytical approach used in the analysis of monolexemic Anglicisms. For the sake of comparison, illustration and the applicability of the model, some examples of noun phrases from the economic terminology in Russian, Slovene and Serbian are also provided. The article is divided into three major sections. It starts with the theoretical background of the field, the methodology and corpus description, which is followed by the definition of noun phrase citation form, and the explanation of different noun phrase structures. The central part deals with the analysis of Anglicism noun phrases within the framework of transmorphemisation, and the third part presents analytical examples for a potential description of Anglicism noun phrases in the aforementioned Slavic languages.

\section{Theoretical Background, Methodology and the Corpus}

The methodology used in this paper is comparative and qualitative. The comparative part is concerned with the comparison of English models and Croatian replicas, whereas the qualitative part with the quality of morphological substitution/adaptation of replicas in the receiving language. The main methodological apparatus for the analytical part of the morphological adaptation is the one elaborated by Rudolf Filipović (cf. 1980, 1981, 1986, 1990, 1995) which, for the sake of saving space, will not be described here in detail. Filipović $(1995,109)$ states that:

[t] hereare three types of transmorphemisation: (a) zero transmorphemisation, (b) compromise transmorphemisation, (c) complete transmorphemisation. Zero transmorphemisation takes place when a model (an English word) is taken over by the receiving language as a free morpheme with a zero bound morpheme. Then the Anglicism corresponds to a replica from a morphological point of view. Compromise or partial transmorphemisation occurs when

See, for example, Filipović (1986, 1990); Görlach (2001, 2002) for Anglicisms; Ajduković (2004) for Russianisms in different Slavic languages; and Sočanac et al. (2005) for adaptation of different European -isms into Croatian.

See, for example, Fabijanić (2005). 
a loan, the citation form of an Anglicism, keeps a final bound morpheme that does not conform to the morphological system of the receiving language and keeps the form of a compromise replica on the morphological level. Complete transmorphemisation takes place when an English bound morpheme is replaced by a borrowing-language bound morpheme (a suffix) with the same function. The process is based on the fact that a compromise replica tends to become a replica and to conform to the morphological system of the receiving language.

Adaptation of a model depends on its form. It can have a structure of a free morpheme with a zero bound morpheme or a free morpheme with a bound morpheme (two monoradical or polyradical words, at least), either from a lending or a receiving language. Importation of morphemes is a gradual process and is represented by the scheme: model - compromise replica - integrated replica. Basic (citation) and compromise forms are adapted during the primary adaptation process, whereas receiving language morphemes are adapted during the process of secondary adaptation (see, for example, Filipović 1986).

The same principles of morphemic substitution and adaptation will be applied in the analysis of Anglicism noun phrases (ANP) in this work. However, the analysis will be improved by innovative approaches in dealing with polyradical words adapted in different constituents of ANPs, whose morphemic structure needs a slightly different analytical method.

The paper presents the adaptation analysis of approximately 80 ANPs in Croatian, together with 24 ANPs in Russian, seven in Slovene, and eight in Serbian. For the sake of presenting a wider scope of terms, ANPs were collected from various economic fields, i.e., from the fields of business, investment, finance, accounting, bookkeeping, monetary economy, insurance, banking, management, marketing, stock exchange terminology, and so on. As to the transparency and easier comprehension of the adaptational stages, specific abbreviations and indices were used. Adaptation at the morphological level (transmorphemisation) is illustrated by the use of index $\mathrm{M}$, together with a numeral for a corresponding adaptational degree, i.e., 0 for zero transmorphemisation, 1 for compromise transmorphemisation, and 2 for complete transmorphemisation. For the examples of models and replicas, abbreviations EN for English, HR for Croatian, RU for Russian, SL for Slovene, and SR for Serbian are used.

\section{Definition of the Citation Form of ANPs}

The citation or basic form of ANPs is formed according to the morphological rules of the receiving language and the secondary adaptation of Anglicisms. The order of constituents does not have to be changed, however, they both have to be adapted by the degree of complete transmorphemisation. If the constituents in a noun phrase have been reordered, they have to be adapted with the corresponding rection and the case form of the receiving language. As to the latter, it is usually realized with a noun inflected either in a genitive (e.g., HR imidž brenda) or, in some situations, a dative case (e.g., RU директор по маркетингу).

\section{The Structure of ANPs}

An ANP consists of two or more words, i.e., they are polyradical words with (or without) affixational morphemes. These can either be nouns or adjectives in the following combinations: noun + noun (noun adjunct + head of the phrase), (1a), noun as adjective + noun, (1b), adjective + noun (attributive adjective + head of the phrase), (1c). 
a) HR cash flow $<$ EN cash flow

b) HR floor broker < EN floor broker

c) HR financijski supermarket $<$ EN financial supermarket

Various combinations of constituents within the corpus of noun phrases have been attested. All combinations have been determined according to the degree of their morphological adaptation, i.e., according to a corresponding degree of transmorphemisation. The degree of transmorphemisation is determined according to the type of adapted morphemes and the types of possible constituent combinations.

\section{The Analysis of ANPs: An Overview of Structural Components and Transmorphemisation Degrees}

\subsection{Zero Transmorphemisation (M0)}

Zero transmorphemisation refers to ANPs for which both constituents have been adapted by zero transmorphemisation degree (2).

(2) $\mathrm{MO}+\mathrm{MO}$

The structure of NPs can be realized as: noun + noun $(\mathrm{M} 0+\mathrm{M} 0)$, noun as adjective + noun $(\mathrm{M} 0$ $+\mathrm{M} 0)$, or adjective + noun (M0 + M0).

\subsection{Compromise Transmorphemisation (M1)}

Compromise transmorphemisation refers to ANPs whose first constituent is substituted with zero transmorphemisation, the second constituent by compromise transmorphemisation, or vice versa (3). It also refers to those for which both constituents have been substituted by compromise transmorphemisation or the first constituent by zero transmorphemisation and the second constituent by complete transmorphemisation, or vice versa (4). Finally, there is a group whose first constituent has been substituted by compromise transmorphemisation and the second by complete transmorphemisation, or vice versa (5).

$$
\begin{aligned}
& M 0+M 1, M 1+M 0 \\
& M 1+M 1, M 0+M 2, M 2+M 0 \\
& M 1+M 2, M 2+M 1
\end{aligned}
$$

According to the details of respective parts of speech in ANPs, they can be realized as: noun $+\operatorname{noun}(\mathrm{M} 0+\mathrm{M} 1, \mathrm{M} 1+\mathrm{M} 0, \mathrm{M} 1+\mathrm{M} 1, \mathrm{M} 0+\mathrm{M} 2)$, noun as adjective + noun $(\mathrm{M} 1+\mathrm{M} 2)$, or adjective + noun $(\mathrm{M} 0+\mathrm{M} 1, \mathrm{M} 1+\mathrm{M} 0, \mathrm{M} 1+\mathrm{M} 1, \mathrm{M} 2+\mathrm{M} 0, \mathrm{M} 2+\mathrm{M} 1)$.

\subsection{Complete Transmorphemisation}

Complete transmorphemisation refers to ANPs whose first constituent is substituted by zero transmorphemisation and the second by complete transmorphemisation (6), or to those whose first constituent has been substituted by compromise transmorphemisation and the second by the degree of complete transmorphemisation (7). Finally, there are those which consist of constituents substituted by complete transmorphemisation (8). 
(6) $\mathrm{M} 0+\mathrm{M} 2$

(7) $\mathrm{M} 1+\mathrm{M} 2$

(8)

$\mathrm{M} 2+\mathrm{M} 2$

According to the details of the respective parts of speech in ANPs, they can be realized as: noun + noun $(\mathrm{M} 0+\mathrm{M} 2, \mathrm{M} 1+\mathrm{M} 2, \mathrm{M} 2+\mathrm{M} 2)$, noun as adjective + noun $(\mathrm{M} 2+\mathrm{M} 2)$, or adjective + noun $(\mathrm{M} 2+\mathrm{M} 2)$.

\section{Definitions and Examples of Zero, Compromise and Complete Transmorphemisation of ANPs}

\subsection{The Definition of Zero Transmorphemisation of ANPs}

An unchanged order of constituents in an ANP does not necessarily mean its adaptation according to the degree of the zero transmorphemisation, because reordered constituents can also be adapted with free morphemes. ${ }^{3}$ However, the most frequent pattern would be the one which includes the lending language bound morphemes in at least one of the constituents (9).

(9) HR back-ø office-ø $<$ EN back-ø office-ø

HR wholesale-ø bank-ø $<$ EN wholesale-ø banking

Therefore, the definition of zero transmorphemisation describes the ANPs which have been adapted to the receiving language either with the combination of constituents from the lending language or with reordered constituents. They consist of two English free morphemes with zero bound morphemes. The corpus provided the ones combined of two nouns, a noun used as an adjective combined with another noun or the ones combined of an adjective and a noun.

\subsubsection{Zero Transmorphemisation of ANPs with Noun + Noun or Noun as Adjective + Noun Combinations}

The models consist of two noun constituents or of a noun used as an adjective in combination with a noun. The constituents in replica are formed of English free and zero bound morphemes (10). The ANPs are of the M0 + M0 type.

$$
\begin{aligned}
& \text { HR bear-ø market-ø < EN bear-ø market-ø } \\
& \text { HR cash-ø flow-ø < EN cash-ø How-ø } \\
& \text { HR Dow-ø Jones-ø < EN Dow-ø Jones-ø } \\
& \text { HR full-ø time-ø job-ø }<\text { EN full-ø time-ø job-ø } \\
& \text { HR master- } \varnothing \text { budget- } \varnothing<\text { EN master-ø budget-ø } \\
& \text { HR task-ø force-ø }<\text { EN task-ø force-ø }
\end{aligned}
$$

Since there were no examples of such Anglicisms in Croatian, for the sake of exemplification, we bring several Anglicisms in Russian. These are RU своп коктейль < EN cocktail swap and RU опцион пут < EN put option. More about ANPs in the Russian language can be found in chapter 7. 


\subsubsection{Zero Transmorphemisation of ANPs with Adjective + Noun Structure}

Both constituents have a zero bound morpheme - the former in the positive degree and the latter in the nominative case, singular form, (11). The ANPs are formed according to the M0 + M0 type.

$$
\begin{aligned}
& \text { HR big-ø bath-ø < EN big-ø bath-ø } \\
& \text { HR bottom-ø line- } \varnothing<\text { EN bottom-ø line-ø } \\
& \text { HR evergreen- } \emptyset \text { credit- } \varnothing<\text { EN evergreen- } \emptyset \text { credit- } \varnothing \\
& \text { HR free- } ₫ \text { enterprise- } ₫<\text { EN free- } ₫ \text { enterprise- } ₫
\end{aligned}
$$

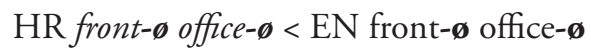

$$
\begin{aligned}
& \text { HR open-ø shop-ø < EN open-ø shop-ø } \\
& \text { HR red-ø herring- } ₫<\text { EN red-ø herring- } \varnothing
\end{aligned}
$$

\subsection{Definition of Partial/Compromise Transmorphemisation of ANPs}

ANPs which have been adapted with at least one constituent containing a bound morpheme from the lending language will be considered as adapted according to the rules of partial/compromise transmorphemisation with various types of constituent combinations (12). These combinations presuppose their further adaptation according to complete transmorphemisation. The definition of partial/compromise transmorphemisation describes the adaptation of ANPs whose first or second constituent is adapted either with a zero or bound morpheme from the lending language, or with a bound morpheme from the receiving language. In cases when the first constituent is an adjective, it does not have to be adapted by the degree of complete transmorphemisation with a respective word agreement.

$$
\mathrm{M} 0+\mathrm{M} 1, \mathrm{M} 1+\mathrm{M} 0, \mathrm{M} 1+\mathrm{M} 1, \mathrm{M} 0+\mathrm{M} 2, \mathrm{M} 1+\mathrm{M} 2, \mathrm{M} 2+\mathrm{M} 0, \mathrm{M} 2+\mathrm{M} 1
$$

\subsubsection{Partial/Compromise Transmorphemisation of ANPs with Noun +}

\section{Noun Structure}

The examples of this type of adaptation are formed according to the type of M1 + M0, and the lending language bound morphemes are: $-s,-i n g,-e r,-a l$ and -s (13).

$$
\begin{aligned}
& \text { HR terms of trade- } \boldsymbol{\varnothing}<\text { EN terms of trade- } \boldsymbol{} \\
& \text { HR šoping centar- } \boldsymbol{\varnothing}<\text { EN shopping centre- } \boldsymbol{} \\
& \text { HR traveler's check- } \boldsymbol{\varnothing}<\text { EN traveller's cheque-ø }
\end{aligned}
$$

ANPs with two English free and bound morphemes are formed according to the type of M1 + M1, and the lending language bound morphemes are: -s, -ing and -er (14).

$$
\begin{aligned}
& \mathrm{HR} \text { insider dealing }<\mathrm{EN} \text { insider dealing } \\
& \mathrm{HR} \text { insider trading }<\mathrm{EN} \text { insider trading }
\end{aligned}
$$




\subsubsection{Partial/Compromise Transmorphemisation of ANPs with Adjective +}

\section{Noun Structure}

In this type of adaptation, adjectives are transferred in their original form of the positive degree. They are made of English free and zero bound morphemes, whereas nouns consist of English free and bound morphemes. The examples of this type of adaptation are formed according to the $\mathrm{M} 0+\mathrm{M} 1$ type, and the lending language (whether derivational or inflectional) morphemes are: -s, -ing, -er, -ment, (15).

$$
\begin{aligned}
& \text { HR blue-ø chip/-s }<\text { EN blue-ø chip(-s) } \\
& \text { HR odd-ø dates < EN odd-ø date(-s) } \\
& \text { HR public- } ₫ \text { relations }<\text { EN public- } ₫ \text { relations } \\
& \text { HR direct-ø costing < EN direct-ø costing } \\
& \text { HR front-ø runner }<\text { EN front-ø runner } \\
& \text { HR lean-ø menedžment }<\text { EN lean-ø management } \\
& \text { HR top-ø menedžment }<\text { EN top-ø management }
\end{aligned}
$$

\subsubsection{ANPs with Adjectives Formed of Free and Bound Morphemes, and Combined with Nouns Formed of Free and Zero Bound Morphemes}

A slightly different situation is with ANPs which consist of English adjectives formed of free and bound morphemes, and combined with nouns formed of free and zero bound morphemes. Examples of this type of adaptation are formed according to the M1 + M0 type, and the lending language morphemes are -ic, -ing and -ed, (16).

(16) HR Baltic exchange- $\varnothing<$ EN the Baltic exchange- $\varnothing$

HR closing day- $\emptyset<$ EN closing day- $\varnothing$

HR levereged buyout $-\varnothing<$ EN leveraged buyout-ø

$\mathrm{HR}$ revolving/rivolving credit/kredit- $\varnothing<\mathrm{EN}$ revolving credit-ø

HR revolving fond- $ø<$ EN revolving fund-ø

HR sinking fund-ø $<$ EN sinking fund-ø

\subsubsection{Adaptation of ANPs with English Bound Morphemes in Both}

\section{Constituents}

The following examples describe the adaptation of ANPs with English bound morphemes in both constituents - adjectives and nouns. They are formed according to the type of M1 + M1. The lending language bound morphemes are $-a l$, -ed and $-y$ for adjectives, and $-i n g,-t y,-s$ for nouns, (17).

(17) $\quad$ HR deferred payment $<$ EN deferred payment

HR Financial times $<$ EN the Financial Times

HR gilt-edged securities < EN gilt-edged securities 
HR global sourcing $<$ EN global sourcing

$\mathrm{HR}$ predatory pricing $<\mathrm{EN}$ predatory pricing

HR strategic marketing < EN strategic marketing

\subsubsection{Partially Adapted ANPs with one Constituent Adapted by Complete Transmorphemisation}

In Filipović $(1986,1990)$ we find solutions for borrowed monomorphic lexemes which were adapted by the rules of complete transmorphemisation. Our corpus and analysis suggest a different solution for those ANPs which, in their adaptation to the morphological categories of the receiving language, have undergone various types of substitutions. We think that in defining the final stage of ANPs' adaptation, all stages of every individual constituent in a phrase have to be taken into consideration. This means that it is not sufficient for an ANP, for which at least one constituent has been adapted by complete transmorphemisation, as in the case of nouns whose gender has been changed from English masculine to Croatian feminine, to be considered as adapted by the degree of complete transmorphemisation. Since the latter examples are not representatives of the final stage in an ANP's substitution and adaptation (see subchapter 6.3), the aforementioned cases are classified as those adapted according to the rules of partial/ compromise transmorphemisation.

The justification for this approach is found in the fact that the whole process of an ANP's adaptation is to be taken in consideration, with all its confirmed (and possibly unconfirmed) combinations, if we want to specify a related degree of its adaptation in the receiving language (according to specific rules of word agreement in a language, of course). For example, had an ANP, like HR spot transakcija (M0 + M2) < EN spot transaction, been adapted with a form of ${ }^{*}$ spotovska transakcija, *spotska transakcija or *transakcija spota, it would have been the case of complete transmorphemisation (M2 + M2), or, to be precise, those would be the final forms in the whole sequence of other adaptational forms, as presented in Table 1.

TABLE 1. The sequence of adaptational forms for the replica spot transakcija.

\begin{tabular}{|l|l|l|c|}
\hline MODEL & \multicolumn{2}{|l|}{ DEGREE } & REPLICA \\
\hline \multirow{5}{*}{ spot transaction } & 1st & $\mathrm{M} 0+\mathrm{M} 0$ & - \\
\cline { 3 - 4 } & \multirow{5}{*}{ 2nd } & $\mathrm{M} 0+\mathrm{M} 1$ & - \\
\cline { 3 - 4 } & & $\mathrm{M} 1+\mathrm{M} 0$ & - \\
\cline { 3 - 4 } & $\mathrm{M} 1+\mathrm{M} 1$ & - \\
\cline { 3 - 4 } & $\mathrm{M} 0+\mathrm{M} 2$ & spot transakcija \\
\cline { 3 - 4 } & $\mathrm{M} 1+\mathrm{M} 2$ & - \\
\cline { 3 - 4 } & $\mathrm{M} 2+\mathrm{M} 0$ & - \\
\cline { 3 - 4 } & $\mathrm{M} 2+\mathrm{M} 1$ & - \\
\cline { 3 - 4 } & \multirow{3}{*}{$3 \mathrm{rd}$} & \multirow{2}{*}{$\mathrm{M} 2+\mathrm{M} 2$} & $\begin{array}{c}{ }^{*} \text { spotovska transakcija } \\
{ }^{*}{ }_{\text {spotska transakcija }}\end{array}$ \\
\cline { 3 - 4 } & & & ${ }^{*}$ transakcija spota \\
\hline
\end{tabular}


A similar situation can be observed in Table 2 where a compromise replica marketinški menedžer is its final form, without any M2 + M2 confirmed forms.

TABLE 2. The sequence of adaptational forms for the replica marketinški menedžer.

\begin{tabular}{|c|c|c|c|}
\hline MODEL & \multicolumn{2}{|c|}{ DEGREE } & REPLICA \\
\hline \multirow{10}{*}{ marketing manager } & $1 \mathrm{st}$ & $\mathrm{M} 0+\mathrm{M} 0$ & - \\
\hline & \multirow[t]{7}{*}{$2 \mathrm{nd}$} & $\mathrm{M} 0+\mathrm{M} 1$ & - \\
\hline & & $\mathrm{M} 1+\mathrm{M} 0$ & - \\
\hline & & $\mathrm{M} 1+\mathrm{M} 1$ & marketing menedžer \\
\hline & & $\mathrm{M} 0+\mathrm{M} 2$ & - \\
\hline & & $\mathrm{M} 1+\mathrm{M} 2$ & * menedžer marketinga \\
\hline & & $\mathrm{M} 2+\mathrm{M} 0$ & - \\
\hline & & $\mathrm{M} 2+\mathrm{M} 1$ & marketinški menedžer \\
\hline & \multirow{2}{*}{$3 \mathrm{rd}$} & \multirow{2}{*}{$\mathrm{M} 2+\mathrm{M} 2$} & - \\
\hline & & & - \\
\hline
\end{tabular}

\subsubsection{ANPs Adapted by Compromise Transmorphemisation and with One Constituent Completely Transmorphemised}

The group of ANPs adapted by compromise transmorphemisation and with one constituent completely transmorphemised is represented by English models formed of nouns or nouns as adjectives combined with other nouns, whereas in Croatian they are represented by two noun combinations $(\mathrm{M} 0+\mathrm{M} 2)$. A replica's first constituent contains a free morpheme with an English zero bound morpheme, and the second contains a free morpheme with the receiving language bound morpheme, i.e. $-a$, (18).

(18) HR cost-benefit/kost-benefit- $\boldsymbol{\emptyset}$ analiz $\boldsymbol{a}<$ EN cost-benefit-ø analysis-ø

HR greenfield-ø investicija < EN green field-ø investment-ø

HR spin-offlspin off-ø kompanija $<$ EN spin-off-ø company-ø

HR spot-ø transakcija $<$ EN spot-ø transaction-ø

HR trend-ø analiza $<$ EN trend-ø analysis-ø

Another type of ANP is represented by a replica which conforms to the rules of M2 + M1 adaptational type and has adjective + noun structure. The first element may be formed of the receiving language bound morphemes for adjectives formation $(-s k i,-n i)$, and the second retains the lending language bound morphemes (-ing, -ment), (19).

(19) HR financijski inženjering < EN financial engineering

HR financijski leasing $<$ EN financial leasing

HR financijski menedžment $<$ EN financial management

$\mathrm{HR}$ viralni marketing $<\mathrm{EN}$ viral marketing 


\subsection{Definition of the Complete Transmorphemisation of ANPs}

The third degree of substitution or complete transmorphemisation of ANPs describes the adaptation of Anglicisms for which both elements have been integrated by complete transmorphemisation or by a reordered structure of constituents with the corresponding morphemic material. A changed order of constituents is also designated by the corresponding rection and a change of case form of constituents in the receiving language.

\subsubsection{Complete Transmorphemisation of ANPs with Noun + Noun Structure}

The first group of examples has the noun + nounstructure adapted by complete transmorphemisation and formed according to the M0 + M2 type, in which the first constituent stays unchanged but the second is changed by the corresponding case form. In our corpus the cases are either genitive or accusative. The replica's first constituent contains a free morpheme with a zero bound morpheme, and the second contains a root morpheme with a receiving language inflectional morpheme, i.e., $-a,(20)$.

$$
\begin{aligned}
& \text { HR imidž- brend } \boldsymbol{a}<\text { EN brand-ø image-ø } \\
& \text { HR efekt-ø output } \boldsymbol{a}<\text { EN output-ø effect-ø }
\end{aligned}
$$

The second group, formed according to the M1 + M2 type, consists of noun + noun replicas in which both constituents are formed of root morphemes with lending language bound morphemes, e.g.: -ant, -or, -er, -ment, -ing, along with the addition of the receiving language inflectional morpheme $-a,(21)$.

$$
\begin{aligned}
& \mathrm{HR} \text { konzultant za menedžment }<\text { EN management consultant } \\
& \mathrm{HR} \text { direktor marketinga }<\text { EN marketing director } \\
& \mathrm{HR} \text { menadžer marketinga }<\text { EN marketing manager }
\end{aligned}
$$

The first example in (21) shows an additional feature, which is the use of a preposition $z a$ ('for') within the NP, and with same function of introducing a genitive or accusative form of the second constituent.

\subsubsection{Complete Transmorphemisation of ANPs with Noun as Adjective + Noun Structure}

Both constituents are adapted by the degree of complete transmorphemisation, i.e., according to the M2 + M2 type. The first constituent is formed of free English morphemes combined with Croatian bound morphemes for adjectives, e.g.: $-n a,-s k-/-5 k-,-s t v$, and with the addition of corresponding receiving language inflectional morphemes, e.g.: $-a$, $-o$, and $-e$ (22). The first example in (22) contains a derivational morpheme -ica for the formation of diminutives.

$$
\begin{aligned}
& \text { HR kreditna kartica < EN credit-ø card-ø } \\
& \text { HR debitna kartica }<\text { EN debit-ø card-ø } \\
& \text { HR kreditna linij } \boldsymbol{a}<\text { EN credit-ø line- } \boldsymbol{\emptyset}
\end{aligned}
$$


HR holdinška kompanija $<$ EN holding company-ø

HR internetsko bankarstvo < EN internet-ø banking

HR marketinške komunikacije $<$ EN marketing communications

\subsubsection{Complete Transmorphemisation of ANPs with Adjective + Noun Structure}

Complete transmorphemisation of ANPs with the adjective + noun structure has the features of the M2 + M2 type. Both constituents in replicas have undergone the degree of complete transmorphemisation and have the same order of constituents as the one found in models. Adjectives are adapted with the receiving language bound morpheme $-s k$-, and nouns are formed with a feminine gender morpheme $-a$ (23). In the third example of (23), we also note the adapted giving language bound morpheme $-a l$.

(23) HR financijska piramida $<$ EN financial pyramid-ø

HR menedžerska revolucija $<$ EN managerial revolution-ø

HR multinacionalna kompanija $<$ EN multinational company-ø

\subsubsection{Complete Transmorphemisation of ANPs with Reordered Noun + Noun Structure}

These ANPs are adapted by complete transmorphemisation and formed according to the M2 + M2 type, in which the first constituent is in the nominative case with a derivational morpheme $-(a) n j e$, and has changed gender from masculine into feminine $(-a)$. The second constituent is in the genitive case with the corresponding inflectional morpheme $(-a,-e)$. Both constituents in replicas contain either free and zero bound morphemes or free and inflectional morphemes (24).

$$
\begin{aligned}
& \text { HR analiza trenda }<\text { EN trend-ø analysis-ø } \\
& \text { HR supervizija banke }<\text { EN bank-ø supervision } \\
& \text { HR minglanje menadžera }<\text { EN manager mingling }
\end{aligned}
$$

\section{Further Perspectives of the Analytical Approach and Research}

So far, the analysis of ANPs in Russian computer and economic terminology has also shown the applicability of this transmorphemisational approach (see, for example, Fabijanić 2003, 2007, $2008,2010,2011$ ), and there are many examples of noun phrases that conform to the proposed model with regard to their adaptation. We thus present here some examples of ANPs for different degrees of transmorphemisation in Russian, $(25 \mathrm{a}-\mathrm{i})$ :

$$
\begin{aligned}
& \text { а) noun + noun, М0 + М0 } \\
& \text { RU боттом-ø лайн-ø }<\text { EN bottom-ø line-ø } \\
& \text { RU Доу-ø Джонс-ø }<\text { EN Dow-ø Jones-ø } \\
& \text { RU джамбл-ø сейл-ø }<\text { EN jumble-ø sale-ø }
\end{aligned}
$$


RU фул-тайм-ø джоб-ø < EN full-time-ø job-ø

RU импульс-ø пёчес-ø < EN impuls-ø purchase-ø

RU кэм-ø флоу-ø < EN cash-ø flow-ø

RU своп-ø коктейль-ø < EN cocktail-ø swap-ø

RU опцุион-ø пут-ø < EN put-ø option-ø

b) adjective + noun, M0 + M0

RU лейм-ø дак-ø < EN lame-ø duck-ø

RU франт-ø офис-ø < EN front-ø office-ø

RU форвард-ø пёчес-ø $<$ EN forward-ø purchase-ø

c) adjective + noun, M0 + M1

RU биг-ø бизнес < EN big-ø business

RU блю-ø чип-c < EN blue-ø chip-ø

RU паблик-ø рилейшнз < EN public relation-s

d) adjective + noun, M1 + M0

RU лимитед компани-ø < EN limited company-ø

RU слипинг партнёр-ø < EN sleeping partner-ø

e) noun + noun, M1 + M1

RU лидз энд лэгз < EN leads and legs

f) adjective + noun, M1 + M1

RU Файнэншл таймс < EN The Financial Times

g) noun + noun, $\mathrm{M0}+\mathrm{M} 2$

RU план-ø маркетинга < EN marketing plan-ø

RU анализ-ø тренд $\boldsymbol{a}<$ EN trend-ø analysis-ø

RU банк-ø клиринговый < EN clearing bank-ø

h) noun + noun, M1 + M2

RU клиринг чеков < EN check-ø clearing

i) adjective + noun, M2 + M2

RU консалтинговая компания < EN consulting company-ø

RU финансовые фьючерсы < EN financial futures

Preliminary results for ANPs in Slovene and Serbian have shown similar results. We present here some examples of several different formational patterns for their adaptation (examples (26a-d) for Slovene, and examples (27a-e) for Serbian). Accordingly, in our forthcoming research we shall be dealing with the study of ANPs in Slavic languages, primarily within the South Slavic group of languages, which will give us a more transparent and systematic image of their adaptation. 
a) noun + noun, M0 + M0

SL spoil-ø sistem-ø $<$ EN spoil-ø system-ø

b) noun + noun, M1 + M1

SL recourse-ø faktoring $<$ EN recourse-ø factoring

c) noun + noun, M1 + M2

SL faktoring financiranje < EN factoring financing

d) adjective + noun, M2 + M2

SL kreditna kartica $<$ EN credit-ø card-ø

SL kreditna linija $<$ EN credit-ø line-ø

SL horizontalna segregacija $<\mathrm{EN}$ horizontal segregation

SL vertikalna segregacija $<$ EN vertical-ø segregation

a) noun + noun, M1 + M0

SR revolving credit- $\varnothing<\mathrm{EN}$ revolving credit-

b) adjective + noun, M2 + M0

SR bilateralni monopol-ø < EN bilateral monopoly-ø

SR budžetski plan-ø < EN budget-ø plan-ø

c) adjective + noun, M2 + M1

SR kreditni clearing $<$ EN credit-ø clearing

SR bilateralni kliring $<$ EN bilateral clearing

d) adjective + noun, M2 + M2

SR bazna industrij $\boldsymbol{a}<\mathrm{EN}$ basic industry-ø

e) noun + noun, M2 + M2

SR akumulacija kapitala < EN capital accumulation

$\mathrm{SR}$ analiza rizika $<\mathrm{EN}$ risk-ø analysis-ø

\section{Conclusion}

In this paper we have proposed and confirmed the approach to classification and analysis of ANPs according to three different adaptational degrees of transmorphemisation: zero, partial/ compromise and complete transmorphemisation. The principles of substitution have been applied in consonance with the combination of their constituents and according to the presence or absence of either lending or receiving language bound morphemes.

Zero transmorphemisation describes the ANPs which have been adapted to the receiving language either with a combination of constituents found in the lending language or with reordered constituents, and consist of two English free morphemes with zero bound morphemes. The ANPs are formed according to the M0 + M0 transmorphemisation type for noun + noun, noun as adjective + noun, or adjective + noun combinations. Partial/compromise transmorphemisation describes the adaptation of ANPs whose first or second constituent is adapted either with a lending 
language zero or bound morpheme, or with a receiving language bound morpheme. According to the details of the respective parts of speech in ANPs, they can be realized as: noun + noun $(\mathrm{M} 0+\mathrm{M} 1, \mathrm{M} 1+\mathrm{M} 0, \mathrm{M} 1+\mathrm{M} 1, \mathrm{M} 0+\mathrm{M} 2)$, noun as adjective + noun $(\mathrm{M} 1+\mathrm{M} 2)$, or adjective + noun (M0 + M1, M1 + M0, M1 + M1, M2 + M0, M2 + M1). Complete transmorphemisation describes the adaptation of ANPs for which both elements have been integrated by complete transmorphemisation or by a reordered structure of constituents with the corresponding morphemic material from the receiving language, and changed by the corresponding case form. In our corpus the cases used are either genitive, accusative or dative. According to the details of respective parts of speech in ANPs, they can be realized as: noun + noun $(\mathrm{M} 0+\mathrm{M} 2, \mathrm{M} 1+\mathrm{M} 2$, $\mathrm{M} 2+\mathrm{M} 2)$, noun as adjective + noun (M2 + M2), or adjective + noun (M2 + M2).

\section{References}

Ajduković, Jovan. 2004. Uvod u leksičku kontaktologiju. Teorija adaptacije rusizama. Beograd: Foto Futura.

Fabijanić, Ivo. 2003. “Anglicizmi u ruskoj kompjuterskoj terminologiji.” MA thesis, University of Zadar.

—. 2005. "Ruski računalni žargon.” In Jezik u društvenoj interakciji. Zbornik radova Hrvatskog društva za primijenjenu lingvistiku, edited by Nada Ivanetić and Boris Pritchard, 155-176. Zagreb-Rijeka: Hrvatsko društvo za primijenjenu lingvistiku.

—. 2007. "Transmorfemizacija imeničkih sintagma na primjeru anglicizama u ruskoj računalnoj terminologiji." Croatica et Slavica Iadertina III: 165-172.

—. 2008. "Anglizmi u ruskoj i hrvatskoj ekonomskoj terminologiji." PhD diss., Univeristy of Zadar.

—. 2010. "Reinterpretacija elipse u formiranju anglizama." Rasprave Instituta za hrvatski jezik i jezikoslovlje 36 (2): 251-273.

—. 2011. "Reinterpretacija transmorfemizacije anglizama-imeničkih sintagma u ruskome i hrvatskom jeziku." Fluminensia: Časopis za flološka istraživanja 23 (1): 67-83.

Filipović, Rudolf. 1980. "Transmorphemisation: Substitution on the Morphological Level Reinterpreted." Studia Romanica et Anglica Zagrabiensia (SRAZ) 25 (1-2): 1-8.

—. 1981. "Morphological categories in linguistic borrowing." Studia Romanicaet Anglica Zagrabiensia (SRAZ) 26 (1-2): 197-207.

—. 1986. Teorija jezika u kontaktu. Zagreb: Školska knjiga.

—. 1990. Anglicizmi u hrvatskom ili srpskom jeziku: porijeklo, značenje, razvoj. Zagreb: Školska knjiga.

—. 1995. "The Theoretical background of the Project The English Element in European Languages." Studia Romanica et Anglica Zagrabiensia (SRAZ) 42: 105-110.

Görlach, Manfred. 2001. A Dictionary of European Anglicisms. A Usage Dictionary of Anglicisms in Sixteen European Langauges. Oxford: Oxford University Press.

—, ed. 2002. English in Europe. Oxford: Oxford University Press.

Sočanac, Lelija et al. 2005. Hrvatski jezik u dodiru seuropskim jezicima. Zagreb: Nakladni zavod Globus.

\section{Sources}

Babić, Ante. 2001. Englesko-hrvatski ekonomski rječnik. Zagreb: Mate.

Bačlija, Irena, ed. 2013. Tematski slovar upravnega menedžmenta. Ljubljana: Fakulteta za družbene vede. http:// www.fdv.uni-lj.si/docs/default-source/zalozba/tematski-slovar-upravnega-mened\%C5\%BEmenta.pdf. 
Bahtijarević-Šiber, Fikreta, and Pere Sikavica. 2001. Leksikon menedžmenta. Zagreb: Masmedia.

Baletić, Zvonimir, ed. 1996. Ekonomski leksikon. Zagreb: Leksikografski zavod “Miroslav Krleža” and Masmedia.

Black, John. 2003. A Dictionary of Economics. Oxford: Oxford University Press.

Čulina, Katarina. 1998. Glosar hrvatsko-engleski ekonomskopravnoga nazivlja. Zagreb: Glosema.

Downes, John, and Jordan E. Goodman. 2006. Dictionary of Finance and Investment Terms. New York: Barron's.

Encyclopaedia Britannica. 1994-1998. CD-ROM.

Etzel, Barbara. 2003. Webster's New World Finance and Investment Dictionary. Indianapolis: Wiley Publishing.

Fišer, Darja. 2007. “Glosar ekonomskih izrazov.” http://lojze.lugos.si/ -darja/resources/glossaries/economics. html.

Jurković, Melita, and Asima Selaković, eds. 2006. Englesko-hrvatski poslovni rječnik/Dictionary of business. Zagreb: Školska knjiga. 2006.

Leko, Vlado. 1998. Rječnik bankarstva i financija. Zagreb: Masmedia.

Leko, Vlado, and Neven Mates, eds. 1993. Rječnik bankarstva i financija. Zagreb: Masmedia.

Merriam Webster's Collegiate Dictionary. Encyclopaedia Britannica. 1994-1998. CD-ROM.

Parkinson, Dilys, and Joseph Noble, eds. 2005. Oxford Business English Dictionary for Learners of English. Oxford: Oxford University Press.

Radoš, Ljerka, and Marcel Meler. 2002. Englesko-hrvatski rječnik nazivlja u marketingu. Osijek: Ekonomski fakultet u Osijeku.

Savic, Jelena. "Englesko-Srpski Recnik Finansijskih Pojmova." https://www.scribd.com/doc/37718493/Englesko-Srpski-Recnik-Finansijskih-Pojmova.

Sofer, Morry. 2005. Russian Business Dictionary. Rockville: Schreiber Publishing.

Špiljak, Višnja. 2000. Englesko-hrvatski poslovni rječnik. Zagreb: Masmedia.

Vlada RS. 2000-2017. "Evroterm, večjezična teminološka zbirka." http://www.evroterm.gov.si.

Жданова, Ирина. 2006. Русско-английский экономический словарь. Москва: Русский язык - Медиа.

Жданова, Ирина, Марина Скворцова. 2008. Русско-английский словарь: Банки, Биржи, Бухгалтерский учет. Москва: Русский язык - Медиа.

Крупнов, Виктор. 2005. Русско-английский бизнес словарь. Москва: Астрель АСТ.

Лозовский, Леонид [и др.]. 2006. Управление. Финансы. Русско-английский словарь. Москва: Русский язык - Медиа.

Пивовар, Аркадий. 2003. Большой англо-русский финансово-экономический словарь. под ред. В. И. Осипова. Москва Издательство: Экзамен.

Райзберг, Борис, Леонид Лозовский, Елена Стародубцева. 2006. Современный экономический словарь. Москва: ИНФРА-М.

Толковый словарь по бизнесу, коммерции и маркетингу, под общ. ред. П. Ф. Пероченко. Москва. 1992. 